Удк 003.334(091)

\title{
Писана традиција Јермена: шеснаест векова писма, књиге и библиотека
}

\author{
Биљана М. Ђурашиновић \\ biljana.djurasinovic@gmail.com
}

\begin{abstract}
Сажетак
У раду је представљена књижна култура Јермена од стварања писма у 5. веку до савременог доба. Посебна пажња посвећена је манастирским скрипторијумима и библиотекама који су, кроз неколико векова, с обзиром на специфичан географски положај јерменске државе и народа, били најзначајнији, а врло често и једини чувари култа књиге и читања. Са штампарском и издавачком делатношћу започело се од 16. века, првенствено у великим европским и светским центрима, да би у првој половини 19. века штампарија била отворена и у јерменској престоници Јеревану. Национална библиотека Јерменије оснива се средином 19, а већина других тек у 20. веку. Деловање јавних библиотека посебно је изражено од двадесетих година прошлог века, док се прве специјалне библиотеке оснивају десетак година касније. Савремено библиотекарство развија се у складу са утицајем информационих технологија, не занемарујући писану традицију, која се, код Јермена, у непрекинутом низу, негује већ хиљаду и шест стотина година.
\end{abstract}

Кључне речи: Јерменија, христијанизација, писмо, књига, образовни центри, манастири, скрипторијуми, библиотеке, 5-20. век, штампарство, издаваштво.

Увод

Није неприродно да се припаднику народа који своју традицију и веру, са локалним карактеристикама, баштини из византијског културног круга наметне идеја подробнијег истраживања друштва и културе Јермена. ${ }^{1}$ Овај стари хришћански народ, о коме генерално мало знамо, близак је Србима по вери, али и по историји коју у многим сегментима делимо. Констатујући да на српском језику нема релевантне литературе, овај рад представља, између осталог, и покушај да се истакну карактеристичне фазе развоја јерменске културе, најпре писане и нарочито оне средњег века, у којима је веома видљив утицај Источног римског царства - Византије. Ово се првенствено односи на издржавање и организацију манастира, скрипторијуме и израду рукописа. С обзиром на географски положај који је у средњем веку заузимала Јерменија, на изглед рукописних књига утицале су и западне монархије, али и оријенталне културе. У том контексту и окупација Турака Османлија од неколико стотина година представља још један елемент заједништва између јерменског и српског народа.

1 Процењује се да данас у свету живи 10 милиона Јермена, од чега три у Републици Јерменији. Говоре језиком који припада индоевропској скупини. - Ara Sanjian, "Five Centuries of Armenian Printing, 1512-2012: A Brief outline", in Celebrating the Legacy of Five Centuries of Armenian-Language Book Printing, 1512-2012: Catalogue (Michigan; University of Michigan-Dearborn, The Armenian Research Center: Southfield; The Alex and Marie Manoogian Museum, 2012-2013), 3, preuzeto 30. 9. 2019, http:// www.fresnostate.edu/artshum/armenianstudies/documents/pdf/Celebrating $\% 20$ the $\% 20$ Legacy $\% 20$ of $\% 20$ Five $\% 20$ Centuries $\% 20$ of $\% 20$ Armenian-Language $\% 20$ Book\%20Printing\%20 Exhibit $\% 20$ Booklet.pdf. 
Јерменијаㄹㄹ је током своје дуге историје била изложена различитим утицајима, првенствено великих царстава у окружењу. ${ }^{3}$ У складу са тим се и обим њене територије повећавао или смањивао, па се тако и „савремена Република Јерменија налази на Јужном Кавказу, уз јужну географску границу између Европе и Азије, обухвата подручје од 11.730 квадратних миља и граничи се са Турском, Азербејџаном, Грузијом и Ираном.

Међутим, територија на којој је живео јерменски народ, тзв. Историјска Јерменија 4 била је много већа. Обухватала је, у данашњим оквирима, целу територију савремене Републике Јерменије, североисточну Турску (укључујући планину Арарат), северозападни део Ирана, западне делове Азербејџана и јужну Грузију. ${ }^{5}$ Међусобни односи између различитих народа, који су кроз историју покушавали да покоре Јермене, доводили су до напретка или стагнације у друштвенополитичком и културном животу народ који се, због примања хришћанства већ на почетку 4. века, сматра једном од најстаријих заједница хришћана. ${ }^{6}$

„Око 85-90 процената хришћанских Јермена данас припада Јерменској цркви, ${ }^{7}$ која је аутокефална и део је мале породице оријенталних православних цркава - као Копти, Сиријци и Етиопљани. Такође постоје и римокатоличка и евангелистичка (протестантска) Јерменска

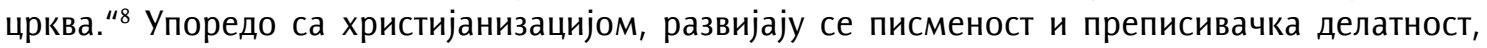
оснивају прве манастирске библиотеке, које су, кроз 1600 година постојања јерменске културе и цивилизације, често биле једини чувари култа књиге и читања. То је посебно видљиво у периодима када су територије насељене Јерменима биле под туђинском влашћу, првенствено Турака Османлија од 16. до 20. и Сафавида, највећим делом током 17. века. Ослобођење од турске власти пратио је погром ${ }^{9}$ јерменског становништва, потпуно уништење културног и верског наслеђа овог древног народа и нестанак, првенствено из области данашње североисточне Турске. Заједно са њима изгубљени су и материјални трагови, али се подаци о развоју писма, књиге и библиотека код Јермена могу пронаћи у записима на крају рукописа, а њихов развој биће детаљније описан у наредним поглављима. ${ }^{10}$

\footnotetext{
2 Као држава први пут се спомиње у запису на Бехистунској стени у некадашњој Персији око 520. г. п.н.е, да би свој највећи процват у античко доба доживела за време владавине Тиграна II Великог између 95. и 55. г. п.н.е. У то доба обухватала је територије које су припадале династији Селеукида и Партској држави, а у историји је позната као Велика Јерменија. У међувремену су римске легије победиле Јермене (током другог века пре наше ере), који су били принуђени да потпишу примирје, а заузврат им је римска власт признала суверенитет. Уследио је период сарадње са Партском државом и Римским царством. Током првог века наше ере, након успостављања мира између Римског царства и Ирана, Тиридата І, оснивача династије Аршакида, признале су обе стране за јерменског краља. - О томе детаљније видети у: Н. А. Машкин, Исӣорија сшиарої Рима (Београд: Научна књига, 1997).

${ }^{3}$ Од хришћанских највећи утицај имали су: Римско, Источно римско царство-Византија и Латинско, а од муслиманских-Османско

${ }^{4}$ У изворима се користи и назив Велика Јерменија.

5 Sanjian, "Five Centuries of Armenian Printing, 1512-2012: A Brief outline", 3.

6 Јерменски краљ Тиридат III примио је хришћанство 301. године, када је и Свети Григорије Просветитељ (око 240-око 332) постао први католикос (у другим источнохришћанским црквама одговара статусу патријарха) Јерменске апостолске цркве са седиштем у Ечмиадзину у данашњој Републици Јерменији. - Agop J. Hacikyan et al., The heritage of armenian literature Vol. 1 from the oral tradition to the golden age (Detroit: Wayne State University Press, 2000), 79-81; 107-108 preuzeto 15. 8. 2019, https:// books.google.rs/books?hl=en\&lr=\&id=uvA-oV0alP8C\&oi=fnd\&pg=PA9\&dq=armenian+illuminators\&ots=_xPNv6UtUm\&sig= 4ZG3El_aANMas)46ILoPFyQN_FE\&redir_esc=y\#v=onepage\& $\mathrm{q}=$ armenian\%20illuminators\&f $=\mathrm{false}$.

7 Прихвата само одлуке три прва васељенска сабора: Никеја (325); Константинопољ (381) и Ефес (431). - Детаљније видети у: Hacikyan, et al., The heritage of armenian literature Vol. 1 from the oral tradition to the golden age, 80-81.

8 Sanjian, "Five Centuries of Armenian Printing, 1512-2012: A Brief outline", 3.

9 Пад султаната пратиће геноцид над јерменским народом, који је започет 1894, да би годину дана касније, тадашње велике силе (Велика Британија, царска Русија, Француска и други) предложиле реформу јерменских провинција у Османском царству, чему се супротставио султан Абдул Хамид II. Упоредо са тим, Јермени су се бунили против лошег положаја и масакра становништва у Провинцијама. Овај напад трајао је до 1896, а следећи, већег обима уследио је 1909, у провинцији Адана, делу некадашње Киликијске Јерменије, када су снаге одане султану, тзв. хамидије, извршиле покољ над јерменским становништвом. За званичан почетак Геноцида, који је трајао све до 1923. узима се 24. април 1915, када су османске снаге, након што су разору жале и убиле јерменске припаднике оружаних снага Царства, започеле са уништењем виђенијих људи из редова јерменског народа. - Rouben Paul Adalian, Historical dictionary of Armenia $2^{\text {nd }}$ edition (Lanham: Toronto: Plymouth: Scarecrowpress, 2010), li-liv preuzeto 26. 7. 2019, https://books.google.rs/books?hl=en\&lr=\&id=QS-vSjHObOYC\&oi=fnd\&pg=PR9\&dq=armenian+monasticism \&ots=wRImNIZDNw\&sig=ZNc4PPiZwM-IXvdgUyznp915YpA\&redir_esc=y\#v=onepage\&q=armenian\%20monasticism\&f=false.

10 Детаљну хронологију развоја јерменског народа и државе, кроз различите епохе и делатност појединаца у њима видети у: Rоuben Paul Adalian, Historical dictionary of Armenia.
} 


\section{Стварање првих центара јерменске писмености}

Творцем јерменског писма сматра се свети Месроп Маштоц (362-440). ${ }^{11}$ Он је по састављању писма, заједно са својим ученицима, започео са подучавањем у неколико јерменских области и основао прву школу у манастиру Амарас. ${ }^{12}$ Са тадашњим католикосом Сахаком Партевим (348-439) $)^{13}$ и ученицима, први пут је превео Библију ${ }^{14}$ на класични јерменски - грабар, који се и данас користи у литургији Јерменске цркве..$^{15}$ Маштоц и Партев, као и њихови настављачи, познати су као „старији“ преводиоци које је пратила и група „млађих“, која се бавила и превођењем дела секуларног карактера. ${ }^{16}$ С обзиром да су Јермени своја знања, посебно у периоду од 4. до 7. века, стицали у великим научним центрима Старог света, као што су Атина, Антиохија, Александрија и други, преписивачко-преводилачки покрет развијао се у складу са тим и омогућио да се дела античких писаца сачувају до данашњих дана. У јерменској књижевности овај период познат је као „Хеленска школа“ (јерм. Јунабан Дпроц). ${ }^{17}$ Велики део философских текстова, који је преведен на јерменски језик везује се за неоплатоничарску школу из Александрије, ${ }^{18}$ што је од значаја због њиховог преноса изван центара у којима су створени. На основу тога су поједини текстови александријске школе пренесени у Багдад, а касније и на запад, ${ }^{19}$ преко Кордобе и Толеда. ${ }^{20}$

Преводилачка активност опада током периода арапске превласти (од 650. до 884), ${ }^{21}$ али се упркос томе, захваљујући раду учених појединаца, попут Стефаноса Сјунетсија, ${ }^{22}$ писца патристичке литературе, може пратити континуитет те делатности. Он је током 8. века посетио и Константинопољ, где се упознао са неколико Јермена, који су му показали садржај фонда библиотеке Свете Софије и помагали му при превођењу дела Псеудо-Дионисија Ареопагита. ${ }^{23}$

11 Детаљније видети у: Hacikyan, et al., The heritage of armenian literature Vol. 1 from the oral tradition to the golden age, 85-91.

12 Детаљније видети у: Jasmine Dum-Tragut, "The cultural impact of armenian monasticism a brief note on the role of armenian monasteries in medieval armenian society", in Monastic life in the Armenian church - Glorious past - Ecumenical Reconsideration, ed. Jasmine Dum Tragut, Dietmar W. Winkler (Wien: Lit Verlag, 2018), 30-31, preuzeto 18. 7. 2019, https://books.google.rs/books?hl= en\& $\mid r=\& i d=y K x 9 D w A A Q B A / \& o i=f n d \& p g=P A 25 \& d q=a r m e n i a n+m i n i a t u r e+v a s p u r a k a n \& o t s=89 X K w 2 n l z H \& s i g=u S 9 n / c l 0 Q H-$ udvDZ5TgJUrm2LcM\&redir_esc=y\#v=onepage\& $q=$ armenian $\% 20$ miniature $\% 20$ vaspurakan\& $f=$ false.

13 Детаљније видети у: Hacikyan et al, The heritage of armenian literature Vol. 1 from the oral tradition to the golden age, 107-108.

14 У почетку се преводило са сиријске верзије Библије, а након сабора у Ефесу, 431. године, када су јерменски представници добили копије, урађен је поновни преглед и усклађен са грчким оригиналима. - Hacikyan, et al., The heritage of armenian literature Vol. 1 from the oral tradition to the golden age, 96.

15 То је уједно и један од најстаријих превода Светог писма у историји. - Hacikyan et al, The heritage of armenian literature Vol. 1 from the oral tradition to the golden age, 96

${ }^{16}$ Детаљније видети у: Hacikyan et al., The heritage of armenian literature Vol. 1 from the oral tradition to the golden age, 95-99.

${ }_{17}$ Valentina Calzolari Bouvier, "The reception and the transmission of the Greek cultural heritage in Armenia: the Armenian translations of the Greek Neoplatonic Works", in Greek Texts and Armenian Traditions, F. Gazzano, L. Pagani and G. Traina (Berlin: De Gruyter, 2016), 47-51, preuzeto 7. 7. 2019, http://archive-ouverte.unige.ch/unige:104263.

18 Оснивач и главни представник неоплатонизма био је Плотин (3. в. н.е) који је прво учио философију у Александрији, затим обишао поједине философске школе на Оријенту и настанио се као учитељ у Риму. Неоплатонизам, као правац, био је супротстављен хришћанству, које је већ у доба његовог стварања имао велики број следбеника. Философија је настојала да задржи своја изворна начела и да Бога остави веровању, док се хришћанска наука трудила да својој вери подвргне свако рационално сазнање. - Nevenka Vejnović, Historija filozofije: sa odabranim filozofskim tekstovima: udžbenik za gimnaziju (Zagreb: Školska knjiga, 1965), 28.

19 Детаљније видети у: Биљана М. Ђурашиновић, „Књижна култура Арапа у средњем веку“, у Библиошека кроз време: Прилози

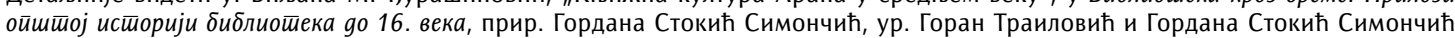
(Панчево: Градска библиотека; Београд: Филолошки факултет, 2017), 187-192.

${ }^{20}$ Calzolari Bouvier, "The reception and the transmission of the Greek cultural heritage in Armenia...", 54-55.

21 Детаљније видети у: Adalian, Historical dictionary of Armenia, xxxv.

22 Детаљније видети у: Agop J. Hacikyan et al., The heritage of armenian literature Vol. 2 from the sixth to the eighteenth century (Detroit: Wayne State University Press, 2002), 137-139, preuzeto 15. 8. 2019; https://books.google.rs/books?id=2gZzD0N9ld $8 C \& p g=P A 652 \& l p g=P A 652 \& d q=$ metzop+monastery\&source=bl\&ots=dkfwNq5pOE\&sig=ACfU3U3ySee92wBr9E9tEBcUUBilUOd3_g\&hl=en\&sa=X\&ved=2ahUKEwi1gLyb4Z7kAhWRIIsKHdskA60Q6AEwAXoECAkQAQ\#v=onepage\&q=metzop\%20 monastery\& $\mathrm{f}=\mathrm{false}$.

${ }^{23}$ Calzolari Bouvier, "The reception and the transmission of the Greek cultural heritage in Armenia...", 51. 
Након што су, под династијама Багратуни у 9. веку ${ }^{24}$ и Ардсруни у 10. веку, ${ }^{25}$ Јермени повратили своју независност, започео је нови друштвенополитички и културни напредак, што је утицало и на преписивачку и преводилачку делатност. Краљевска власт била је распоређена у оквиру накхарар система, у коме су богате породице поседовале земљиште, припадајуће заједнице и ствари, а уз њихову подршку одвијала се и културна делатност. Друштвени живот се за време династија Багратуни одвијао у Анију ${ }^{26}$ и Карсу, ${ }^{27}$ а у време династије Ардсруни у историјској јерменској области Васпуракана. ${ }^{28}$ У овом периоду посебно се развијала архитектура, али су се у оквиру старих и новоизграђених манастира учени монаси бавили и преписивачком делатношћу, што ће нарочито доћи до изражаја за време постојања Киликијског краљевства, ${ }^{29}$ у западном делу Јерменије од 1080. до 1375. године. За Краљевство су од посебног значаја биле владавине две династије: Рубенида (владали од 1080. до 1219), чији је оснивач Рубен био у служби краља Гагика II Багратунија (владао од 1042. до 1045) који је 1080. освојио тврђаву Вахка и успоставио власт над територијама у њеној околини и Хетумида (владали од 1230. до 1375), чији је оснивач био краљ Хетум, са седиштем у тврђавама Лемброн и Баберон.

Краљеви из рода Рубенида и Хетумида били су оснивачи неколико манастира у Киликији, у оквиру којих су и мушкарци и жене могли да науче вештине читања и писања. ${ }^{30}$ Поред сакралних текстова, превођена су и дела из медицине, пољопривреде и права. С обзиром на односе које су представници Киликијског краљевства имали са краљевинама и царевинама и на Истоку и на Западу, ${ }^{31}$ превођење је, поред дотадашњег арапског, сиријског и грчког, вршено и са старофранцуског. Преводи киликијског периода могу се препознати по двема карактеристикама: представљају „слободне“ преводе који се врло често разликују од оригиналног текста, док се, као језик световних текстова користио средњејерменски, уместо класичног грабара. На овај начин могуће је пратити развој јерменског језика, који ће, неколико векова касније довести до стварања модерне књижевне верзије - ашкхарабара. ${ }^{32}$

Упркос разуђености етничког и културног простора, преписивачки центри и манастирске библиотеке средњовековне Јерменије постојали су у оквиру целокупне територије на којој су живели Јермени, али су, посебно на изглед публикација, утицале државе и народи са којима су, током овог периода, имали непосредни контакт. Поред религијске функције, манастири су били и значајни образовни центри, а скрипторијуми су се користили и за израду публикација које су биле неопходне у образовању монаха, као и њихових ученика.

24 Оснивач династије био је краљ Ашот I (владао од 885. до 890) коме су власт над Јерменима признали и византијски цар у Константинопољу и абасидски халиф у Багдаду, што је, након неколико векова нестабилности, омогућило поновни развој. - Adalian, Historical dictionary of Armenia, xxxvi.

25 Краљевство Васпурака основано је 908. године за време владавине краља Симбата І Багратунија (владао од 890. до 914). Краљ Гагик I Ардсруни, прво као принц једног дела Краљевства (владао од 904. до 908), а касније преузима управу над целим Васпураканом (владао од 908. до 937/943). - Детаљније видети у: Hacikyan et al., The heritage of armenian literature Vol. 2 from the sixth to the eighteenth century, 183.

${ }^{26}$ Јерменско краљевство Ани је 1045. припојено Византији, да би 1064, након неколико година од првих напада на источни део Царства, Турчин Алп Арслан заузео град Ани. - Adalian, Historical dictionary of Armenia, xxxviii.

27 Град је, као такав опстао до 1065. године. - Детаљније видети у: Hacikyan et al., The heritage of armenian literature Vol. 2 from the sixth to the eighteenth century, 185.

28 У страху од Турака Селџука наследници краља Гагика I (владао од 989. до 1019) 1022. предају круну византијском цару и селе се у Кападокију (регион Себастије/Сиваса). - Детаљније видети у: Hacikyan et al., The heritage of armenian literature Vol. 2 from the sixth to the eighteenth century, 184.

29 Настанку Киликијског краљевства претходио је почетак владавине Турака Селџука над Јерменијом 1064. Седам година касније (1071), Источно римско царство - Византија, након битке код Манцикерта, губи превласт у источном делу државе, што се одразило и на судбину свих источнохришћанских народа, па и јерменског. - Детаљније видети у: Hacikyan et al., The heritage of armenian literature Vol. 2 from the sixth to the eighteenth century, 185.

${ }^{30}$ Детаљније видети у: Hacikyan et al., The heritage of armenian literature Vol. 2 from the sixth to the eighteenth century, 181-209.

31 Након похода крсташа ка Светој земљи, територије на којима су се налазили Јермени у Киликијској краљевини долазе у додир са њима и то посебно са Францима. - Детаљније видети у: Hacikyan et al., The heritage of armenian literature Vol. 2 from the sixth to the eighteenth century, 187.

32 Hacikyan et al, The heritage of armenian literature Vol. 1 from the oral tradition to the golden age, 102-103. 


\section{Скрипторијуми, образовни центри и манастирске библиотеке средњовековне Јерменије}

Током средњег века, скрипторијуми и манастирске библиотеке развијали су се у мери у којој су биле стабилне прилике у којима је живео јерменски народ. Постоје докази о постојању манастира и у 4, али се велике камене структуре појављују у 10. веку. Њихов развој наставио се следећа четири века, додавањем звоника, библиотека, великих сала за окупљање и учионица. Значајан број њих постали су центри високог школства који су изнедрили неколико добро познатих песника, философа и учењака-вардапета, ${ }^{33}$ са којима су, приликом пресељења, ишли и њихови ученици, који су желели да усвоје знања учитеља. ${ }^{34}$ Један од њих био је и Зеноб Глак. ${ }^{35}$ На основу његовог сведочења у оквиру првог дела књиге Исшиорија Тарона (јерм. Patmutiun Taronо), чији је аутор, на место старешине манастира Светог Јована Претече у Тарону (јерм. Сурб Карапет) поставио га је Григорије Просветитељ. Манастир је касније назван Глакаванк. ${ }^{36}$

Током 10. века су у провинцији Лори изграђени манастири Санахин (966) и Хагпат (976), које је помагала краљица Хосрованјуш, жена Ашота III Багратунија (владао од 951. до 977). ${ }^{37}$ Библиотека манастира Санахин потиче из 12. века, а саграђена је у северном делу манастирског комплекса. ${ }^{38}$ Значајну библиотеку имао је и манастир Гошаванк, изграђен у 13. веку. ${ }^{39}$

Током 13. и 14. века, за време владавине Монгола, постојали су бројни скрипторијуми у источном делу Историјске Јерменије, а међу најстаријима је био онај у манастиру Гладзор. ${ }^{40}$ Преписивана су дела Платона, Аристотела, Старог и Новог завета, а колофони шездесет девет рукописа насталих у манастиру указују да су углавном стварани за унутрашње потребе. Са манастиром Гладзор повезан је и Нораванк, који је био задужбина породице Орбелијан, на чијем се поседу он налазио, заједно са припадајућом имовином.

Школа у Гладзору ${ }^{41}$ била је под утицајем делатности вардапета Нерсеса из Муша у 13. веку, а ученици су првенствено били из Киликије и са обала језера Ван. Следећи век обележен је делатношћу његовог ученика Јесаије Нтчетсија. ${ }^{42}$

33 Верски учитељ са највишим квалификацијама. - D. Tsaghikyan, "Grigor Tatevatsi and the sacraments of initiation" (Thesis for the degree doctor of phil., The University of Edinburgh, 2014), 27, preuzeto 20. 8. 2019, https://www.era.lib.ed.ac.uk/bitstream/ handle/1842/11790/Tsaghikyan2015.pdf? sequence $=$.

${ }^{34}$ Hacikyan et al., The heritage of armenian literature Vol. 2 from the sixth to the eighteenth century, 207

35 О Зенобу Глаку детаљније видети у: Hacikyan et al., The heritage of armenian literature Vol. 2 from the sixth to the eighteenth century, $100-116$.

36 Манастир Глакаванк уништен је 1916.

37 Adalian, Historical dictionary of Armenia, xxxvii.

38 Грађевина и данас постоји. - José Calvo-López et. al. Geometry and capriciousness in $11^{\text {th }}$ - century Armenian architecture. The scriptorium of the monastery of Sanahin, preuzeto 25. 7. 2019, https://www.academia.edu/13102141/Geometry_and_capriciousness_ in_11th-century_Armenian_Architecture._The_Scriptorium_of_the_Monastery_of_Sanahin.

39 Детаљније видети у: Dum-Tragut, "The cultural impact of armenian monasticism...", 34-35.

${ }^{40}$ Helen C. Evans, "Armenians and their middle Age", in Armenia: Art, Religion, and trade in the Middle Ages ed. Helen C. Evans (New York: The Metropolitan Museum of Art; New Haven: Yale University Press, 2018), 32-33, preuzeto 15. 8. 2019, https://books.google.rs/ books?hl=en\&|r=\&id=ezNtDwAAQBAJ\&oi=fnd\&pg=PA29\&dq=gladzor+scriptorium\&ots=hoXF4hisa 8\&sig=1o4NxyZtuk8esaZFQJvP_CUOIQE\&redir_esc $=\mathrm{y} \# \mathrm{v}=$ onepage $\& \mathrm{q}=$ gladzor\%20scriptorium\&f $=$ false.

${ }^{41}{ }^{\prime \prime}(\ldots)$ имала је сопствену структуру са поделом курсева и постигнућа који су водили ка стицању звања варgайеш̄а. Главни план и програм називан је 'интерни и екстерни коментари и преводи', терминологија која се може пронаћи и у Византији. 'Интерни' се односи на знање о Богу које је видљиво кроз божје откровење како је то описано у Светим списима и делима светих отаца који су их коментарисали; 'екстерни' се односи на античке, пре-хришћанске ауторе, чији су философски записи обезбеђивали категорије и терминологију коришћену у хришћанским теолошким расправама. Изван ових темељних предмета који су изучавани у Гладзору, спомињу се и практичније вештине као што су музика и сликање; међутим, то се односило на црквену музику и осликавање рукописа пре него на уметност у ширем смислу." - Mathews and Taylor, The armenian gospels of Gladzor: the life of Christ illuminated, 28;

У Византији је програм школовања обухватао прво опште образовање, enkyklios paideia, које је црква захтевала од будућих свештеника, а састојало се од основних елемената граматике, реторике, па чак и философије.

Теолошка настава је имала три учитеља, који су носили звање didaskalos. Ту је био прво професор Јеванђеља и истовремено ректор. Затим је долазио професор Апостола, који је тумачио Посланице и професор Псалтира. У оквиру монашких школа правом религијском васпитању претходила је општа настава, односно enkyklios paideia. - Luj Breje, Vizantijska civilizacija (Beograd: Nolit, 1976), $438,444$.

42 Thomas F. Mathews and Alice Taylor, The armenian gospels of Gladzor: the life of Christ illuminated (Los Angeles: I. Paul Getty Museum, 2001), 27-29, preuzeto 17. 8. 2019, https://books.google.rs/books?hl=en\&lr=\&id=iR02AgAAQBA/\&oi=fnd\&pg=PP1\&dq=armenian+manuscripts+matenadaran+collection\&ots=_cf8pYYxAq\&sig=Amz-6HAF7at8DA-fiO8RbConUqg\&redir_esc=y\#v=onepage\&q\&f=false. 
Међу писарима који су своју делатност наставили у Гладзору били су и они подучавани у Киликији, па се постепено и у оквиру њега развио стил сличан ономе који су научили у области из које су се доселили. Овај утицај видљив је у раду То́роса из Тарона, главног писара Гладзора, посебно у орнаменталним композицијама, у коришћењу симбола јеванђелиста за први иницијал сваког Јеванђеља уместо слова која су користили уметници ранијих периода из ове области. Један од ученика ове школе био је и сликар Аваг (око 1300-1360), који је своју делатност обављао у периоду од 1329. до 1358. године, ${ }^{43}$ и то у Киликији, Сјунику, Табризу и другде. Од њега је сачувано седам рукописа. ${ }^{44}$ Сарађивао је и са једним од најбољих писара и илуминатора 14. века Саргисом Пицаком. Главно седиште у коме је обављао своју делатност налазило се у Сису, али је понекад одседао у Дразарку ${ }^{45}$ и другим манастирима. Створио је скоро педесет потписаних рукописа или оних који му се могу приписати. ${ }^{46}$

Манастир Татев ${ }^{47}$ основан је 895. године. Током векова је неколико пута био рушен и пљачкан, што је утицало и на стање фондова Библиотеке. До данашњих дана је од њега сачувано само 109 рукописа насталих између 14. и 18. века, док их се у касном 12. веку у Библиотеци налазило више од 1000. Све до шездесетих година 19. века није могуће утврдити тачан број рукописа у оквиру Манастира. Данас се у Матенадарану ${ }^{48}$ налази 147 који се могу повезати са манастирском библиотеком. ${ }^{49}$

Поред манастира у Источној Јерменији, значајну улогу имали су и они у западном делу земље, попут Хоромоса, у близини престонице династије Багратида - Анија, чији комплекс зграда је стваран између 10. и 13. века, као један од највећих у средњовековној Јерменији и на целом хришћанском Истоку. ${ }^{50}$ Са школом у Анију и овим скрипторијумом може се повезати и настанак Јеванђеља Муїни у 11. веку. ${ }^{51}$

У оквиру појединих области налазили су се и други преписивачки центри, као што је манастир Аргелан у области Васпуракан, на североисточној обали језера Ван, где је скрипторијум радио од 1251. до краја петнаестог века. ${ }^{52}$ Од великог значаја за културу јерменске књиге био је и манастир Вараг или Варагаванк. Његово оснивање може се повезати са Григоријем

${ }^{43}$ The Chester Beatty library: a catalogue of the armenian manuscripts, With an introduction on the history of armenian art Sirarpie der Nersessian, Vol. I (Dublin: Hogges Figgis\&Co. Ltd, 1958), xxix, xxxii, preuzeto 20. 9. 2019, https://chesterbeatty.ie/assets/uploads/2018/11/A-Catalogue-of-the-Armenian-Manuscripts-VOL-I-TeXT-Opt_Part1.pdf.

${ }^{44}$ Vrej Nersessian, Treasures from the ark: 1700 years of armenian christian art (Los Angeles: J. Paul Getty Museum, 2001), 167168. preuzeto 14. 8. 2019, https://books.google.rs/books?id=2vxGAgAAQBA/\&pg=PA184\&lpg=PA184\&dq=scribes+of+horomos+monastery\&source $=$ bl\&ots $=$ VIxz1TkvZM\&sig $=$ ACfU3U2CBRGSpH0RzboAuLvWtY7A4Af6Yw\&hl=en\&sa $=X \& v e d=2 a h U-$ KEwjx4aKo0OLkAhXm_CoKHZRNDN4Q6AEwFnoECAkQAQ\#v=onepage\&q=scribes\%20of\%20horomos\%20 monastery\&f=false.

45 О манастиру детаљније видети у: Samvel Grigoryan, The location of Drazark, burial place of the kings and queens of Armenia and the "Blessed Rubenians", preuzeto 24. 8. 2019, https://www.academia.edu/33673878/The_location_of_Drazark_burial_place_of_the_ kings_and_queens_of_Armenia_and_of_the_blessed_Rubenians_in_English_.

${ }^{46}$ Sirarpie Der Nersessian and Sylvia Agemian, Miniature Painting inthe Armenian Kingdom of Cilicia from the Twelfth to the Fourteenth Century (Washington: Dumbarton Oaks Research Library and Collections, 1993), 142, preuzeto 16. 7. 2019, https://books. google.rs/books?id=q4hb_94801 AC\&pg=PA45\&lpg=PA45\&dq=hromkla+scriptorium\&source=bl\&ots=ZHBJPkAkDj\&sig=ACfU3U2WqBjGtU1jGICSPbgt9RU1BBRsaQ\&hl=en\&sa=X\&ved=2ahUKEwiH9aqRxJfkAhUDwsQBHSu_CUMQ6AEwDnoECAkQAQ\#v=onepage\& $q=$ hromkla\%20scriptorium\&f=false.

47 У оквиру манастира радио је и један од најобразованијих Јермена свога доба Григор Татеватси (1346 - око 1410). На почетку каријере био је и уметнички писар. Према сачуваним подацима рукописа који се данас чува у Матенадарану у оквиру универзитета Татев постојало је писарско одељење, а поред изучавања израде минијатура учило се и цртање портрета и пејзажа. - Tsaghikyan, "Grigor Tatevatsi and the sacraments of initiation", 54, 58-60.

48 Институт древних рукописа Месропа Маштоца. - Sanjian, "Five Centuries of Armenian Printing, 1512-2012: A Brief outline", 4

${ }_{49}$ Tsaghikyan, "Grigor Tatevatsi and the sacraments of initiation", 47-48, 52.

50 Armen Kazaryan, "The Zhamatun of Horomos: The Shaping of an Unprecedented Type of Fore-church Hall", Kunst texte 3 (2014) 1, preuzeto 14. 8. 2019, https://www.academia.edu/12322629/The_Zhamatun_of_Horomos_The_Shaping_of_an_Unprecedented_Type_of_Fore-church_Hall_in_kunsttexte.de_Nr._3_2014_14_Seiten_www.-_kunsttexte.de.

51 Име је добио по цркви Мугни у Тбилисију (Грузија), где се некада налазио. Данас се чува у Матенадарану. - Детаљније видети y: Nersessian, Treasures from the ark: 1700 years of armenian christian art, 161.

52 Ibid, 187. 
Лусаворовичем (Григоријем Просветитељем, 257-331) и причом о Светој Хрипсими, ${ }^{53}$ а касније ширење манастирског комплекса везује се за чланове породице Ардсруни. ${ }^{54}$

Од школа за украшавање рукописа које су постојале на територији Западне Јерменије, веома је значајна и она која се развијала у региону око Себастије/Сиваса, Кесарије/Кајсерија, Мелитене/Малатје и даље северно од Киликије. Блиски контакти између јерменских монаха у источном делу Кападокије са византијском уметничком традицијом кападокијског православља, која је у тој области опстајала већ неколико векова, имала је значајан утицај на јерменски начин украшавања рукописа. Група од 16 илустрованих, који представљају монастички или провинцијски стил, једини су уметнички или културни остаци који потичу из ове области пре 13. века. У већини случајева сликари, који су највероватније били и монаси, истовремено су и преписивали текстове Јеванђеља. Кроз њих је сачувана уметност која своје порекло баштини из модела раних година стварања слика у хришћанству, помешаних са елементима из византијске традиције насталих непосредно након иконоборачко ${ }^{55}$ периода 9. и 10. века и, у појединим случајевима, позајмљених из зидног сликарства Кападокије. Упркос томе, задржали су јак оријентални изглед, који је био у супротности са натуралистичким, карактеристичним за грчке рукописе..$^{56}$

У оквиру сеобе Јермена из подручја Кападокије и планине Таурус, након њиховог пада под власт Селџука, налазили су се и врсни писари и уметници, који су своју делатност наставили у Киликијској Јерменији, под влашћу династија Рубенида и Хетумида. У овој области истакнути преписивачки центри били су: Дразарк, ${ }^{57}$ Хромкла, Скевра и Сис. У оквиру манастира Дразарк створено је једино познато дело прве половине 12. века - Јереванско јеванђеље које се чува у Матенадарану. ${ }^{58}$

Средином 13. века, под управом католикоса Констандина I, у обновљеном скрипторијуму и успостављеном патријархату ${ }^{59}$ у Хромкли, илуминатор То́рос Рослин (активан од 1256. до $1268)^{60}$ стварао је рукописе у новом, натуралистичком стилу са новостима у сликању ликова које су утицале на јерменску уметност кроз средњи век. У свим значајнијим местима Киликије, која су укључивала манастир Скевра, скрипторијум у главној тврђави Хетумида Лемброну и касније у престоници Сис, израђивани су рукописи који су осликавали богатство и престиж Краљевства. ${ }^{61}$ Писари су остављали податке о покровитељству католикоса, епископа и старешине манастира из места која су се налазила у близини Хромкле, па није изузетак да су и рукописи из друге половине 12. века директно или индиректно повезани са овим манастиром. С обзиром на везе које су постојале између скрипторијума у Скеври и Хромкли и израда

${ }_{53}$ О Григорију Просветитељу и Светој Хрипсими детаљније видети у: Evans, "Armenians and their middle Age", 29.

${ }^{54}$ Nairy Hampikian, "The architectural heritage of Vaspurakan and the preservation of memory layers", in Armenian Van/Vaspurakan, ed. Richard G. Hovannisian (Costa Mesa: Mazda Publishing, 2000), 102, preuzeto 18. 7. 2019, https://www.academia. edu/8497831/The_Architectural_Heritage_of_Vaspurakan_and_the_Preservation_of_Memory_Layers.

55 Односи се на култ поштовања светих слика и осликавања, који је осуђен у 8. веку, јер је у периоду иконоборства било дозвољено само симболично представљање Бога: крст, света тајна причешћа и реч Божија. - Детаљније видети у: Мишел Каплан, Визаншиија (Београд: Clio, 2008), 199-203.

${ }^{56}$ Dickran Kouymjian, The Melitene Group of armenian miniature painting in the eleventh century, 81-83, preuzeto 23. 8. 2019, http:// www.fresnostate.edu/artshum/armenianstudies/documents/pdf/2014-DK-Armenian\%20Kayseri.pdf.

57 Од свих манастира и светилишта Дразарк је највише био повезан са краљевском породицом Рубенида и, поред тога што је био значајан културни центар, служио је и као гробно место припадника вишег племства и чланова цркве. Према јерменским средњовековним изворима, основао га је или обновио велики принц То́рос I Рубенид (око 1100-1129) у првој половини његове владавине. Први пут се спомиње 1113, а правила су успоставили вардапети Георг Мелрик и Кивракос, који су били и његове прве старешине. - Grigoryan, The location of Drazark, burial place of the kings and queens of Armenia and the "Blessed Rubenians", 61-62.

58 Der Nersessian and Agemian, Miniature Painting inthe Armenian Kingdom of Cilicia from the Twelfth to the Fourteenth Century, 2.

59 Седиште Јерменске цркве од 1149. до 1293; потом је премештено у Сис, где се налазило све до 1441. године када, након пада Киликијског краљевства „мајка“ црква свих Јермена поново постаје Ечмиадзин што је остао и до данашњих дана. - Детаљније видети у: Adalian, Historical dictionary of Armenia, xl-xlii.

60 Детаљније видети на: World Digital Library, T'oros Roslin Gospels, preuzeto 27. 2. 2020, https://www.wdl.org/en/item/13012/.

${ }^{61}$ Evans, "Armenians and their middle Age", 35 
орнаментике одвијала се паралелно. ${ }^{62}$ Поједини скрипторијуми били су посебно развијени док је на њиховом челу био епископ Јован, брат киликијског краља Хетума I, а постојало је и неколико радионица. Према доступним подацима, главна је била у Грнеру, али рукописи су копирани и у мање значајним објектима, нпр. у Лисонки и Тироју, у близини Грнера, а Јован не само да је управљао радовима, већ је и сарађивао приликом њихове израде. Обично су два или чак три писара радила заједно у преписивању рукописа, али изгледа да ниједан писар или сликар није имао позицију која се могла поредити са оном То́роса Рослина у Хромкли. ${ }^{63}$ Између 1173. и 1215. писар Григор Мличетси (око 1150-1215) копирао је пет рукописа, од којих су четири настала у скрипторијуму манастира Скевра. Најзначајнији од њих је Књиїа шужбалица из 1173, Григорија из Нарека (око 951-око 1003) ${ }^{64}$ израђена за архиепископа Нерсеса Лембронатсија (1153-1198). ${ }^{65}$

У овој области значајна је и делатност манастира Аваг, који се налазио у оквиру политичке и уметничке сфере града Сиса. У њему је настала чувена књига Пройовеgи из Муша, која представља најдужи јерменски рукопис, а чувала се у манастиру Светих апостола у Мушу. ${ }^{66}$

Они рукописи који су илустровани у Ахтамару, ${ }^{67}$ манастирима на северним и источним обалама језера Ван и самом граду, припадају ванској преписивачкој школи, док су други писани у Хизану, јужно од горепоменутог језера и суседном кантону Моку део Хизанске. ${ }^{68}$ Међу најзначајнијим ученицима ове школе били су браћа Мартирос и Саргис, који су се налазили на челу скрипторијума у коме су преносили знања већем броју писара. Поједини мајстори и ученици су касније отишли у различите центре Јерменије ширећи њен утицаја. Упркос различитим приступима људи који су радили у оквиру скрипторијума, коришћене су истоветне композиције које су научили од својих учитеља. Повезаност са школом у Вану може се делимично објаснити и податком да су оца двојице писара, Мартироса и Саргиса, обучавали уметници у Ахтамару, а писари из Хизана су повремено радили у Вану и у манастирима на северној обали језера Ван, где су се упознали са моделима који су у њима коришћени. ${ }^{69}$ Поред Ахтамара, рукописи су се преписивали и у манастиру Нарек, где је образован и 977. заређен Григорије из Нарека. ${ }^{70}$ У оквиру манастирске школе предавао је све до своје смрти теологију и религијска знања. ${ }^{71}$ Активност хизанског скрипторијума прекинута је у првој четвртини 17. века, иако су писари наставили свој рад у суседној провинцији Мок. ${ }^{72}$

Године 1502. у Јерменији се успоставља власт иранске династије Сафавида, а 14 година касније, све територије историјски насељене Јерменима потпадају под власт Турака Османлија. Почетком 17. века Сафавиди освајају јереванску тврђаву и она постаје административни центар граничне провинције, а након сукоба између Сафавида и Османлија, Јермени из Јулфе (јерм. Џуга) бивају пресељени у Нову Јулфу (јерм. Нор Џуга) поред Исфахана, на територији Ирана. ${ }^{73}$ У оквиру Нове Јулфе, своју делатност обављао је и Месроп из Хизана, који је

\footnotetext{
${ }^{62}$ Der Nersessian and Agemian, Miniature Painting inthe Armenian Kingdom of Cilicia from the Twelfth to the Fourteenth Century, 3, 18.

63 Ibid., 77-78.

${ }^{64}$ Hacikyan et al., The heritage of armenian literature Vol. 2 from the sixth to the eighteenth century, 274-307.

${ }^{65}$ Nersessian, Treasures from the ark: 1700 years of armenian christian art, 162.

66 Ibid., 141, 205.

67 Седиште католикоса од 1113. године. Изградња цркве Светог крста на острву Ахтамар, у оквиру језера Ван, започета је по наредби краља Гагика I Ардсрунија и завршена 921. године. - Adalian, Historical dictionary of Armenia, xxxvi, xxxix.

68 The Chester Beatty library: a catalogue of the armenian manuscripts, xxxiii.

69 Ibid., xxxviii-xxxix.

70 Григорије из Нарека био је један од најзначајнијих писаца мистика у целом хришћанству, а његово дело Књиїа шиужбалииа највољеније дело јерменске литературе, које се по значају може упоредити само са Светим писмом. - Hacikyan et al., The heritage of armenian literature Vol. 2 from the sixth to the eighteenth century, 274.

71 Hacikyan et al., The heritage of armenian literature Vol. 2 from the sixth to the eighteenth century, 275.

72 The Chester Beatty library: a catalogue of the armenian manuscripts, xxxix.

73 Adalian, Historical dictionary of Armenia, xliii-xliv.
} 
осликавање, повезивање и копирање учио у оквиру хизанског скрипторијума. Једна од његових специјалности била је и обнављање старих рукописа. ${ }^{74}$

У престоници Османског царства - Цариграду, јерменска заједница знатно се увећала након установљења Патријархата 1461. године, иако су се писари из редова овог народа тамо могли наћи још у доба Источног римског царства - Византије, на шта указује постојање Јеванђеља из 909. године. Упркос томе, стални скрипторијуми успостављени су тек у 15. веку. Многи преписивачи били су староседеоци из других градова, док су се поједини задржали у граду кратко време. ${ }^{75}$

Може се утврдити да је до данас сачувано највише 35.000 јерменских рукописа. Највећим делом налазе се у Институту за изучавање древних рукописа - Матенадарану у престоници Јерменије - Јеревану (око 11.000 и неколико хиљада фрагмената); око 4000 у Јерменској патријаршији у Јерусалиму и мехтаристичком манастиру на острву Сан Лазаро у Венецији; око 1200 у библиотеци Мехтариста у Бечу; 700 или више у предграђу Исфахана, у Ирану - Новој Јулфи. Остали су расути по различитим колекцијама у јавним и приватним установама широм света. ${ }^{76}$ Из периода до 10. века сачувано их је само осам. ${ }^{77}$

Приликом израде рукописа, у овиру школа и атељеа Велике Јерменије одржаван је континуитет у осликавању већи него код оних у Киликијској школи. ${ }^{78}$ "(..) писац касног шестог и раног седмог века Вртанес Кертог говори о књигама писаним на пурпурном пергаменту, слова обојених златом и сребром, окованих у слоновачу, као познати примерци из његовог доба. (...) Велике колекције рукописа историчари понекад спомињу у опису ратова и инвазија. Стога Стефан Орбелијан пише да су 1170, када су освојили тврђаву Багаберд, Турци Селџуци уништили више од 10.000 рукописа и других драгоцености које су тамо донете на чување из Татева и других манастира и цркава Сјуника. "79 Међу овим рукописима постојале су и разлике у језику, јер је класични јерменски језик 5. и 6. века - грабар у 12. и 13. веку претрпео је значајне промене и није више био говорни, већ се користио у академским и круговима цркве. Стога је писарима средњег века било потребно да имају висок ниво лингвистичких и граматичких знања. ${ }^{80}$ „Писари се жале на дужину текста, врућину и муве које им сметају лети, али и на екстремну хладноћу зими када им се укоче прсти или се мастило смрзне у посуди. (...) Дајући материјалне и нематеријалне вредности рукописима, њихово очување било је ствар од великог значаја, и они су, посебно у каснијим вековима, молили читаоце да не пишу по маргинама, секу слике или уврћу странице; испуштају восак на књигу и да је држе крпом. (...) За време ратова и инвазија носите рукописе у градове и закопајте их, али у мирнодопско време извадите их и читајте, јер су затворене књиге попут идола. ${ }^{\prime 81}$

У складу са наменом рукописа, избор материјала на коме се писало и украсних техника био је различит. На пергаменту су унцијалом писана јеванђеља која су била украшена богатим текстуалним илуминацијама, док су, са много мање украса, на папиру писани школски материјали. Када се, око 9. века развио мањи тип слова - болоргир повећала се количина текста

\footnotetext{
${ }^{74}$ Alice Taylor, Book arts of Isfahan: diversity and identity in Seventeenth-century Persia (Malibu, California: ). Paul Getty Museum, 1995), 51, 54-55, preuzeto 16. 9. 2019, https://books.google.rs/books?id=Gh02AgAAQBAJ\&pg=PA84\&lpg=PA84\&dq=Armenian+an$\mathrm{d}+$ Islamic+Manuscript+Painting:+A+Visual+Dialogue\&source=bl\&ots=8qi-NxTTko\&sig=ACfU3U1Ih0ozLSWM8gLd7xcQUgkdlu9AcQ\&hl=en\&sa=X\&ved=2ahUKEwjF9cii4MXkAhWpxMQBHZBvDBAQ6AEwBnoECAgQAQ\#v=onepage\&q=Armenian\%20 and\%20Islamic\%20Manuscript\%20Painting\%3A\%20A\%20Visual\%20Dialogue $\& f=f a l s e$.

75 The Chester Beatty library: a catalogue of the armenian manuscripts, xlii.

${ }^{76}$ Michael E. Stone, "The Album of Armenian Paleography With some pickings from Armenian colophons", Gazzette du livre médiéval 26 (1995): 8, preuzeto 16. 7. 2019, https://www.persee.fr/doc/galim_0753-5015_1995_num_26_1_1293.

77 Јеванђеље краљице Млке (862); Лазарион (887); преводилаца (996); Дсургут (974); Ашота Спарапета (909); Сансариан (985); Скантчелагортс (988) и Ечмиадзин (989). - Детаљније видети у: Nersessian, Treasures from the ark: 1700 years of armenian christian art, 157.

78 Hacikyan et al., The heritage of armenian literature Vol. 2 from the sixth to the eighteenth century, 208.

79 The Chester Beatty library: a catalogue of the armenian manuscripts.

80 Tsaghikyan, "Grigor Tatevatsi and the sacraments of initiation", 56.

${ }^{81}$ The Chester Beatty library: a catalogue of the armenian manuscripts, xix-xxi.
} 
која се могла исписати у рукописима нормалне величине. ${ }^{82}$ Минијатуре које су се налазиле на насловним и страницама ранијих средњовековних рукописа, међу којима су најистакнутији били јеванђеља и литургијске књиге 12. века, садржајем и наменом биле су под утицајем византијског стила. Западни мотиви такође добијају на значају, посебно у Хромкли у оквиру које је То́рос Рослин израдио посебно лепе примерке. ${ }^{83}$

Јерменске илуминације углавном се заснивају на хришћанској и медитеранској уметности која је развијана у контакту са нехришћанским цивилизацијама Блиског истока. Њени корени налазе се у касној класичној традицији из које је преузела многе декоративне мотиве, као и природан начин приказивања људских фигура, животиња и биљака. Начин илустровања Библије код Јермена преузет је, као и код других хришћанских народа, из уметности која се развијала у Сирији, Палестини, Александрији и Константинопољу. Понекад су позајмљивали типске мотиве из ових области, прилагођавајући их сопственом изразу. ${ }^{84}$

Јерменски повез је такође имао своје специфичности, а на њега су утицали начини повезивања у области Блиског истока и Европе. Уметност повезивања књига у Јерменији започета је са проналаском алфабета и преводом Библије који је уследио непосредно након тога. Није сачувана ниједна књига са повезом до 11. века, а можда чак ни пре 13, а снажан утицај имао је коптски начин повезивања који су Јермени усвојили преко Сирије и Византије. Јерменске и грчке корице биле су дрвене и пресвучене кожом, за разлику од раних коптских повеза, код којих се кожа причвршћивала преко папируса. Код публикација из исламског света кожа се постављала преко картона, а у земљама западног света преко пергамента. ${ }^{85}$

За украшавање коже коришћен је тзв. „слепи“ отисак, који се састојао у утискивању знакова, најчешће крста уз помоћ гвожђа. За разлику од Византинаца, Јермени никада нису користили одређене мотиве, попут животиња, или хералдичка обележја. ${ }^{86}$ У периоду након пада Источног римског царства - Византије, кожни повези јерменских рукописа били су у складу са ранијим декорацијама, док су поједини, посебно они у Новој Јулфи, били под утицајем европских традиција украшавања. Боја коже била је светлија од оне која је коришћена у ранијим периодима у Великој Јерменији и Киликији. Од нових фигура су, под утицајем западног стила, посебно коришћени Христ на крсту и Девица. ${ }^{87}$

Иако је преписивање рукописа настављено све до Првог светског рата, појава прве штампане књиге значајно је допринела повећању издавачке продукције публикација на јерменском језику.

\section{Почеци штампарства и издавачка делатност код Јермена}

Издавачка и штампарска делатност пратила је судбину јерменског народа, који је у 16 . веку, када је издата прва публикација, већ био под снажним утицајем народа из степе, посебно

\footnotetext{
82 О коришћењу материјала за писање, величини и писмима у јерменским рукописима различитих периода детаљније видети у: Dickran Kouymjian, "The Archaeology of the Armenian Manuscript: Codicology, Paleography and Beyond", in Armenian Philology in the Modern Era: From Manuscript to Digital Text, eds. Valentina Calzolari, Michael E. Stone (Leiden; Boston: Brill, 2014), 5-22, preuzeto 30. 9. 2019, https://books.google.rs/books?hl=en\&lr=\&id=ekz3AwAAQBAJ\&oi=fnd\&pg=PR5\&dq=armenian+manuscripts+matenadaran+collection\&ots=gD-ka|xKnc\&sig=DIpSrDHj8eX0wB9SJXAc0EKTI34\&redir_esc=y\#v=onepage\& $q=a r m e n i a n \% 20$ manuscripts $\% 20$ matenadaran $\% 20$ collection $\& f=f a l s e$.

83 Hacikyan et al., The heritage of armenian literature Vol. 2 from the sixth to the eighteenth century, 208.

${ }^{84}$ The Chester Beatty library: a catalogue of the armenian manuscripts, xliv.

${ }^{85}$ Dickran Kouymjian, "From Manuscript to Printed Book: Armenian Bookbinding from the Sixteenth to the Nineteenth Century" (rad predstavljen na 2nd International Symposium Printing and Publishing in the Languages and Countries of the Middle East Paris, France, 2-4 November 2005), 4, preuzeto 18. 8. 2019, http://www.fresnostate.edu/artshum/armenianstudies/documents/ pdf/2008\%20DK\%20BnF\%20Symposium\%20Nov\%202005\%20PDF.pdf.

${ }^{86}$ Dickran Kouymjian, Post-Byzantine Armenian Bookbinding and Its Relationship to the Greek Tradition, 185, preuzeto 18. 8. 2019, http:// fresnostate.edu/artshum/armenianstudies/documents/pdf/2008\%20DK-249-Athens\%20Bookbinding.pdf.

87 Ibid., 193
} 
Турака Османлија. Штампана је заслугом Агопа Мегапарта, односно Грешника, у Венецији 1512, а звала се Урбайиіирк или Књиіа йеш̄ка. Од појаве прве штампане књиге до 1600. створено је седамнаест наслова на јерменском језику. У следећих педесет година двадесет и три, да би између 1650. и 1700. њихов број премашио сто тридесет и пет. ${ }^{88}$ Прва штампарија у Ирану такође је отворена заслугом јерменског бискупа Хачатура из Кесарије, који је око 1630. у манастиру Светог спаситеља у Новој Іулфи отворио школу чији је она била саставни део. ${ }^{89}$ Током 17. века, штампарије публикација на јерменском језику постоје у Риму, Паризу, Амстердаму, Милану, Санкт-Петербургу, Лајпцигу итд, ${ }^{90}$ а 1771 . отвара се и у седишту Јерменске апостолске цркве - Ечмиадзину. Значајно штампарско средиште током 19. века на територији Османске/ Западне Јерменије био је манастир Вараг, а у периоду од 1772. до 1818. и у индијском граду Мадрасу штампа се 40 наслова. ${ }^{91}$ Тамо је излазио први јерменски часопис Азgарар или Весник од 1794. до 1796, а укупно је штампано 18 бројева. У њему су, осим новости из области трговине, економије и политике, објављивани и они о уметности, разни преводи и историјска дела. ${ }^{92}$

Након Првог светског рата, штампарска делатност у Јерменији убрзано се развијала, посебно у престоници Јеревану, док су старији штампарски и издавачки центри доживљавали стагнацију. Са развојем нових технологија ова област, у свим деловима Јерменије, али и изван матичне државе, доживљава убрзани раст.

\section{Развој библиотека у Јерменији током 20. века}

Завршетком Првог светског рата, све до деведесетих година 20. века, долази до развоја различитих типова библиотека, на које је утицала и културна политика тадашњег Савеза Совјетских Социјалистичких Република, која је важила и на територији Јерменије, као њеног саставног дела. ${ }^{93}$ Совјетска национална политика подстицала је културу на националним језицима земаља чланица, што је утицало и на издавачку продукцију. У том контексту се и укупан број наслова штампаних на јерменском језику повећао са 20, колико их је било 1920, до близу 600, тачно деценију касније. Овај тренд се наставио током периода постојања јерменске СССР, а одржава се и данас. Један од старих штампарских и издавачких центара у оквиру престонице, али и на целокупној територији Јерменије, налази се у Ечмиадзину. ${ }^{94}$

Рукописна и штампарска делатност код Јермена, у различитим периодима развоја, омогућила је и појаву библиотека. Као што је детаљније описано у претходним поглављима, током средњег века оне су се налазиле у оквиру манастира, да би од 19. века почели да се успостављају и остали типови: националне, универзитетске и јавне. Данас су најзначајније међу њима: Национална библиотека, Основна научна библиотека академије наука, Библиотека државног универзитета у Јеревану и Републичка научна медицинска библиотека. За образовање ширих слојева друштва од посебног значаја су јавне библиотеке које се развијају у оквиру мреже јеременских библиотека. Њихова сарадња одвија се и у оквиру Јерменског удружења библиотекара основаног 1994. године. ${ }^{95}$

\footnotetext{
88 Sanjian, "Five Centuries of Armenian Printing, 1512-2012: A Brief outline", 5-6.

89 Taylor, Book arts of Isfahan: diversity and identity in Seventeenth-century Persia, 70.

90 Марианна Карленовна Галстян, „Национальная библиотека Армении. Музей армянского книгопечатания“, Весйник Библиоиечной Ассамблеи Евразии 2 (2018): 27-28. преузето 1. 9. 2019, https://vestnikbae.rsl.ru/article/view/53.

91 Sanjian, "Five Centuries of Armenian Printing, 1512-2012: A Brief outline", 14-15.

92 Галстян, „Национальная библиотека Армении. Музей армянского книгопечатания“: 26.

93 Јерменија је 29. новембра 1920. године проглашена совјетском републиком. Две године касније изгласан је устав. Совјетска Јерменија, Грузија и Азербејџан постају део федерације Совјетских Социјалистичких Република Транскавказије, а од 1936. издвојене су у посебне социјалистичке државе. Од 1991. Јерменија је поново самостална република. - Adalian, Historical dictionary of Armenia, Iv-lvi, Ixii.

94 Sanjian, "Five Centuries of Armenian Printing, 1512-2012: A Brief outline", 16.

95 Детаљније видети на: Armenian library association, preuzeto 31. 1. 2020, http://alarmenia.am/?page_id=541\&lang=en
} 
Национална библиотека Јерменије основана је 1832. године и данас садржи око седам милиона јединица библиотечке грађе. ${ }^{96}$ На основу Закона који је донет у оквиру Социјалистичке Јерменије као дела СССР-а, од 1919. године има статус државне установе за чување свих врста публикација. У периоду од 1925. до 1990, када је добила данашњи назив, била је у статусу републичке јавне библиотеке. Од фондова поседује прву јерменску књигу штампану у Венецији између 1512. и 1513, географску карту штампану у Амстердаму 1695, периодично издање, штампано у Мадрасу 1794. године и друга ретка издања. Данас се састоји од неколико одељења и девет специјализованих читаоница. ${ }^{97}$

Основна научна библиотека академије наука Јерменије основана је 1935. године. У склопу својих колекција поседује и 27 посебних, које обухватају радове значајних јерменских уметника и научника. ${ }^{98}$

Библиотека државног универзитета у Јеревану најстарија је високошколска библиотека у Јерменији основана 1920. године и поседује два милиона јединица библиотечке грађе. ${ }^{99}$

Републичка научна медицинска библиотека своју делатност започиње 1939, а данас поседује највећу збирку медицинске литературе од преко пола милиона јединица грађе. ${ }^{100}$ Од 1951. ова установа врши координацију медицинских библиотека у земљи и омогућава доступност медицинских информација преко Мреже медицинских библиотека (ММБ). ${ }^{101}$ ММБ се састоји од библиотека које се налазе на медицинским факултетима, болницама и медицинским организацијама. ${ }^{102}$

Од тридесетих година 20. века постоји и централна градска библиотека „Аветик Исахакјан“ у Јеревану, која је педесет година касније постала матична за 47 огранака. Један је од оснивача конзорцијума јерменских библиотека. ${ }^{103}$

Свака од претходно наведених установа, поред својих карактеристичних функција, у савременом добу има задатак да, применом информационих технологија, обезбеди приступачност што ширем кругу корисника, не занемарујући један од основних задатака сваке библиотеке, очување целовитости сакупљеног људског знања за будућа поколења.

\section{Закључак}

Историја јерменског писма, књиге и библиотека веома је сложен процес у којем су кроз дуги временски период обједињене традиције јерменског народа и култура и цивилизација које су са њим долазиле у додир. У средњем веку то је видљиво кроз начин организације манастира, који представљају најстарије и, до 19. века, једине образовне центре код Јермена. Поред тога, они су имали одлучујући значај у очувању националног идентитета народа, који је, иако суочен са многим препрекама и погромом, успео да очува трагове свог постојања и на територијама које су се нашле изван граница садашње Републике Јерменије. У оквиру манастира постојали су и значајни скрипторијуми и библиотеке, чији се рад, кроз поједине епохе у јерменској историји, може реконструисати само на основу записа на крајевима рукописних књига, као и радова учених људи који су радили у оквиру њих.

\footnotetext{
${ }^{96}$ D. Aram Donabedian, John Carey and Arshak Balayan, "Twenty Years After: Armenian Research Libraries Today". Liber Quarterly: the journal of the association of european research libraries Vol. 22, no. 1 (2012): 7, preuzeto 16. 8. 2019, https://dspace.library.uu.nl/ handle/1874/241651.

97 Галстян, „Национальная библиотека Армении. Музей армянского книгопечатания“: 24-25.

98 Donabedian, Carey and Balayan, "Twenty Years After: Armenian Research Libraries Today": 7

99 Ibid.

100 Ibid.

101 NML - Network of Medical Libraries.

102 Brief history of RSML Preuzeto 29. 9. 2019, http://www.medlib.am/?page=history.

${ }_{103}$ Yerevan Municipality, "City Central Library after Av. Isahakyan", CNCO Communal non commercial organization, preuzeto 27. 1. 2020, http://www.isahakyanlibrary.am/Patmutyun-eng.html.
} 
Деветнаести век је, поред жеље за ослобођењем од вишевековне власти Турака Османлија, омогућио и оснивање националне библиотеке јерменског народа, да би, један век касније, развој доживели и остали типови библиотека. Упоредо са оснивањем библиотека, иако се прва штампана књига на јерменском језику појавила у 16. веку, убрзано се развијају штампарска и издавачка делатност, што је имало утицај и на повећање књижних фондова.

Данас су јерменске библиотеке, као и у већини земаља, вишеслојан систем повезан средствима масовне комуникације. Своје циљеве остварују у складу са интересима државе и локалне самоуправе у области културе и организацијама значајним за развој библиотечкоинформационе делатности, која је, упркос врло често неповољним друштвенополитичким околностима, успела да прати све промене које су се десиле у развоју јерменске културе дугом готово 2000 година.

\section{Литература и извори:}

1. Adalian, Rouben Paul. Historical dictionary of Armenia $2^{\text {nd }}$ edition. Lanham: Toronto: Plymouth: Scarecrowpress, 2010. Preuzeto 26. 7. 2019. https://books.google.rs/books?hl=en$\& \mid r=\& i d=Q S-v S j H O b O Y C \& o i=$ fnd\&pg $=P R 9 \& d q=$ armenian + monasticism\&ots=wRImNIZDNw\&sig=ZNc4PPiZwM-IXvdgUyznp915YpA\&redir_esc=y\#v=onepage\&q=armenian $\% 20$ monasticism\&f $=$ false.

2. Armenian library association. Preuzeto 31. 1. 2020. http://alarmenia.am/?page_id=541\&lang=en.

3. Breje, Luj. Vizantijska civilizacija. Beograd: Nolit, 1976.

4. Brief history of RSML. Preuzeto 29. 9. 2019. http://www.medlib.am/?page=history.

5. Calvo-López José, Miguel Á. Alonso-Rodríguez, Enrique Rabasa Díaz, Ana López-Mozo, Carmen Pérez-Ríos and Pau Natividad-Vivó. Geometry and capriciousness in $11^{\text {th }}$ - century Armenian architecture. The scriptorium of the monastey of Sanahin. Preuzeto 25. 7. 2019. https://www.academia.edu/13102141/ Geometry_and_capriciousness_in_11th-century_Armenian_Architecture._The_Scriptorium_of_the_ Monastery_of_Sanahin.

6. Calzolari Bouvier, Valentina. "The reception and the transmission of the Greek cultural heritage in Armenia: the Armenian translations of the Greek Neoplatonic Works". In Greek Texts and Armenian Traditions, Gazzano, F.; Pagani, L. \& Traina, G, 47-70. Berlin: De Gruyter, 2016. Preuzeto 7. 7. 2019. http:// archive-ouverte.unige.ch/unige: 104263.

7. Der Nersessian, Sirarpie and Sylvia Agemian. Miniature Painting in the Armenian Kingdom of Cilicia from the Twelfth to the Fourteenth Century. Washington: Dumbarton Oaks Research Library and Collections, 1993. Preuzeto 16. 7. 2019. https://books.google.rs/ books?id=q4hb_94801 AC\&pg=PA45\&lpg=PA45\&dq=hromkla+scriptorium\&source=bl\&ots$=$ ZHBJPkAkDj\&sig=ACfU3U2WqBjGtU1jGICSPbgt9RU1BBRsaQ\&hl=en\&sa=X\&ved=2ahUKEwiH9aqRxJfkAhUDwsQBHSu_CUMQ6AEwDnoECAkQAQ\#v=onepage\&q=hromkla\%20 scriptorium\& $\mathrm{f}=\mathrm{false}$.

8. Donabedian, Aram D, Carey John and Arshak Balayan. "Twenty Years After: Armenian Research Libraries Today". Liber Quarterly: the journal of the association of european research libraries Vol. 22, no. 1 (2012): 3-41. Preuzeto 16. 8. 2019. https://dspace.library.uu.nl/handle/1874/241651.

9. Dum-Tragut, Jasmine. "The cultural impact of armenian monasticism a brief note on the role of armenian monasteries in medieval armenian society". In Monastic life in the Armenian church-Glorious past-Ecumenical Reconsideration, ed. Jasmine Dum Tragut, Dietmar W. Winkler, 25-41. Wien: Lit Verlag, 2018. Preuzeto 18. 7. 2019. https://books.google.rs/books?hl=en\&lr$=\& i d=y K \times 9 D w A A Q B A J \& o i=$ fnd\&pg $=P A 25 \& d q=$ armenian + miniature + vaspurakan\&ots $=89 \times K w-$ 2nlzH\&sig=uS9n/cl0QH-udvDZ5TgJUrm2LcM\&redir_esc=y $\# v=$ onepage\&q=armenian\%20 miniature\%20vaspurakan\&f=false. 
10. Đurašinović, Biljana M. „Knjižna kultura Arapa u srednjem veku“. U Biblioteka kroz vreme: Prilozi opštoj istoriji biblioteka do 16. veka. Priredila Gordana Stokić Simončić, urednici Goran Trailović i Gordana Stokić Simončić, 187-192. Pančevo: Gradska biblioteka; Beograd: Filološki fakultet, 2017.

11. Evans, Helen C. "Armenians and their middle Age". In Armenia: Art, Religion, and trade in the Middle Ages, ed. Helen C. Evans, 29-40. New York: The Metropolitan Museum of Art; New Haven: Yale University Press, 2018. Preuzeto 15. 8. 2019. https://books.google.rs/books?hl$=e n \& \mid r=\& i d=e z N t D w A A Q B A J \& o i=f n d \& p g=P A 29 \& d q=$ gladzor + scriptorium\&ots=hoXF4hisa8\&sig=104NxyZtuk8esaZFQJvP_CUOIQE\&redir_esc $=y \# v=$ onepage $\& q=$ gladzor $\% 20$ scriptorium\&f=false.

12. Galstjan, Marianna Karlenovna. „Nacionaljnaja biblioteka Armenii. Muzej armjanskogo knigopečatanija“. Vestnik Bibliotecnoj Assamblej Evrazij 2 (2018): 24-28. Preuzeto 1. 9. 2019. https://vestnikbae.rsl. $\mathrm{ru} / \mathrm{article} / \mathrm{view} / 53$.

13. Grigoryan, Samvel. The location of Drazark, burial place of the kings and queens of Armenia and the "Blessed Rubenians", 61-84. Preuzeto 24. 8. 2019. https://www.academia.edu/33673878/The_location_of_Drazark_burial_place_of_the_kings_and_queens_of_Armenia_and_of_the_blessed_Rubenians_in_English_.

14. Hacikyan, Agop J, Gabriel Basmaijan, Edward S. Franchuk and Nourhan Ouzounian. The heritage of armenian literature Vol. 1 from the oral tradition to the golden age. Detroit: Wayne State University Press, 2000. Preuzeto 15. 8. 2019. https://books.google.rs/books?hl=en\&lr=\&id=uvA-oV0alP8C\&oi=fnd\&pg=PA9\&dq=armenian+illuminators\&ots= xPNv6UtUm\&sig=4ZG3EI_aANMas/46ILoPFyQN_FE\&redir_esc $=y \# v=$ onepage\&q=armenian\%20 illuminators\& $\mathrm{f}=$ false.

15. Hacikyan, Agop J, Gabriel Basmaijan and Edward S. Franchuk. The heritage of armenian literature Vol. 2 from the sixth to the eighteenth century. Detroit: Wayne State University Press, 2002. Preuzeto 15. 8. 2019. https://books.google.rs/books?id=2gZzD0N9Id8C\&pg=PA652\&lpg=PA652\&dq=metzop+monastery\&source $=$ bl\&ots $=$ dkfwNq5pOE\&sig $=$ ACfU3U3ySee92wBr9E9tEBcUUBilUOd3_g\&hl=en\&sa=X\&ved=2ahUKEwi1gLyb4Z7kAhWRIIsKHdskA60Q6AEwAXoECAkQAQ\#v=onepage\&q=metzop\%20 monastery\&f=false.

16. Hampikian, Nairy. "The architectural heritage of Vaspurakan and the preservation of memory layers". In Armenian Van/Vaspurakan, ed. Richard G. Hovannisian, 87-104. Costa Mesa: Mazda Publishing, 2000. Preuzeto 18. 7. 2019. https://www.academia.edu/8497831/ The_Architectural_Heritage_of_Vaspurakan_and_the_Preservation_of_Memory_Layers.

17. Kaplan Mišel. Vizantija. Beograd: Clio, 2008.

18. Kazaryan, Armen. "The Zhamatun of Horomos: The Shaping of an Unprecedented Type of Fore-church Hall“. Kunst texte 3 (2014): 1-14. Preuzeto 14. 8. 2019. https://www.academia.edu/12322629/The_ Zhamatun_of_Horomos_The_Shaping_of_an_Unprecedented_Type_of_Fore-church_Hall_in_kunsttexte.de_Nr._3_2014_14_Seiten_www.-_kunsttexte.de.

19. Kouymjian, Dickran. "From Manuscript to Printed Book: Armenian Bookbinding from the Sixteenth to the Nineteenth Century". Rad predstavljen na 2nd International Symposium Printing and Publishing in the Languages and Countries of the Middle East, Paris, France, 2-4 November 2005, 1-14. Preuzeto 18. 8. 2019. http://www.fresnostate.edu/artshum/armenianstudies/documents/pdf/2008\%20DK\%20 BnF\%20Symposium\%20Nov\%202005\%20PDF.pdf.

20. Kouymjian, Dickran. Post-Byzantine Armenian Bookbinding and Its Relationship to the Greek Tradition, 183196. Preuzeto 18. 8. 2019. http://fresnostate.edu/artshum/armenianstudies/documents/pdf/2008\%20 DK-249-Athens\%20Bookbinding.pdf.

21. Kouymjian, Dickran. „The Archaeology of the Armenian Manuscript: Codicology, Paleography and Beyond". In Armenian Philology in the Modern Era: From Manuscript to Digital Text. Editors Valentina Calzolari, Michael E. Stone, 5-22. Leiden; Boston: Brill, 2014. Preuzeto 30. 9. 2019. https://books.google.rs/books?hl=en\&lr=\&id=ekz3AwAAQBAJ\&oi=fnd\&pg=PR5\&dq=armenian+manuscripts+matenadaran+collection\&ots=gD-kaJxKnc\&sig=DIpSrDHj8eX0wB9SJXAc0EKTI34\&redir_esc=y\#v=onepage\&q=armenian $\% 20$ manuscripts\%20matenadaran\%20collection\&f=false. 
22. Kouymjian, Dickran. The Melitene Group of armenian miniature painting in the eleventh century, 81-93. Preuzeto 23. 8. 2019. http://www.fresnostate.edu/artshum/armenianstudies/documents/pdf/2014-DK -Armenian\%20Kayseri.pdf.

23. Mathews, Thomas F. and Alice Taylor. The armenian gospels of Gladzor: the life of Christ illuminated. Los Angeles: J. Paul Getty Museum, 2001. Preuzeto 17. 8. 2019. https://books.google.rs/books?hl=en\&lr$=\& i d=i R 02 A g A A Q B A J \& o i=f n d \& p g=P P 1 \& d q=$ armenian+manuscripts+matenadaran+collection\&ots= cf8pYYxAq\&sig=Amz-6HAF7at8DA-fiO8RbConUqg\&redir_esc $=y \# v=$ onepage\& $q \& f=f a l s e$.

24. Maškin, N. A. Istorija starog Rima. Beograd: Naučna knjiga, 1997.

25. Nersessian, Vrej. Treasures from the ark: 1700 years of armenian christian art. Los Angeles: J. Paul Getty Museum, 2001. Preuzeto 14. 8. 2019. https://books.google.rs/books?id=2vxGAgAAQBAJ\&pg=PA184\&lpg=PA184\&dq=scribes+of+horomos+monastery\&source=bl\&ot$\mathrm{s}=\mathrm{VIxz1TkvZM \& sig=ACfU3U2CBRGSpH0RzboAuLvWtY7A4Af6Yw \& hl=en \& sa=X \& ved=2ahU-}$ KEwjx4aKo0OLkAhXm_CoKHZRNDN4Q6AEwFnoECAkQAQ\#v=onepage\&q=scribes $\% 20$ of $\% 20$ horomos\%20monastery\&f=false.

26. Sanjian, Ara. "Five Centuries of Armenian Printing, 1512-2012: A Brief outline". In Celebrating the Legacy of Five Centuries of Armenian-Language Book Printing, 1512-2012: Catalogue, 1-24. Michigan; University of Michigan-Dearborn, The Armenian Research Center: Southfield; The Alex and Marie Manoogian Museum, 2012-2013. Preuzeto 30. 9. 2019. http://www.fresnostate.edu/artshum/armenianstudies/documents/pdf/Celebrating\%20the\%20Legacy\%20of\%20Five\%20Centuries\%20of\%20 Armenian-Language\%20Book\%20Printing\%20Exhibit\%20Booklet.pdf.

27. Stone, Michael E. "The Album of Armenian Paleography With some pickings from Armenian colophons". Gazzette du livre médiéval 26 (1995): 8-17. Preuzeto 16. 7. 2019. https://www.persee.fr/doc/ galim_0753-5015_1995_num_26_1_1293.

28. Tsaghikyan, D. "Grigor Tatevatsi and the sacraments of initiation". Thesis for the degree doctor of phil., The University of Edinburgh, 2014. Preuzeto 20. 8. 2019. https://www.era.lib.ed.ac.uk/bitstream/ handle/1842/11790/Tsaghikyan2015.pdf?sequence $=$.

29. Taylor, Alice. Book arts of Isfahan: diversity and identity in Seventeenth-century Persia. Malibu, California: J. Paul Getty Museum, 1995. Preuzeto 16. 9. 2019. https://books.google.rs/books?id$=$ Gh02AgAAQBAJ\&pg=PA84\&lpg=PA84\&dq=Armenian+and +Islamic + Manuscript + Pain ting:+A+Visual+Dialogue\&source=bl\&ots=8qi-NxTTko\&sig=ACfU3U1 lh0ozLSWM8gLd7xcQUgkdlu9AcQ\&hl=en\&sa=X\&ved=2ahUKEwjF9cii4MXkAhWpxMQBHZBvDBAQ6AEwBnoECAgQAQ\#v=onepage\&q=Armenian\%20and\%20Islamic\%20Manuscript $\% 20$ Painting $\% 3 \mathrm{~A} \% 20 \mathrm{~A} \% 20$ Visual\%20Dialogue\&f=false.

30. The Chester Beatty library: a catalogue of the Armenian manuscripts, With an introduction on the history of Armenian art Sirarpie der Nersessian, Vol. I. Dublin: Hogges Figgis\&Co. Ltd, 1958. Preuzeto 20. 9. 2019. https://chesterbeatty.ie/assets/uploads/2018/11/A-Catalogue-of-the-Armenian-ManuscriptsVOL-I-TeXT-Opt_Part1.pdf.

31. Vejnović, Nevenka. Historija filozofije: sa odabranim filozofskim tekstovima: udžbenik za gimnaziju. Zagreb: Školska knjiga, 1965.

32. World Digital Library. T'oros Roslin Gospels. Preuzeto 27. 2. 2020. https://www.wdl.org/en/ item/13012/

33. Yerevan Municipality. "City Central Library after Av. Isahakyan". CNCO Communal noncommercial organisation. Preuzeto 27. 1. 2020. http://www.isahakyanlibrary.am/Patmutyun-eng.htm. 


\section{Armenian Written Tradition: Sixteen Centuries of Script, Books and Libraries}

\section{Summary}

It is not unusual for a member of a nation that inherits its tradition and religion, though with local characteristics, from Byzantine cultural circle, to get the idea of a more detailed exploration of Armenian society and culture. Noting that there is no relevant literature in the Serbian language, this paper represents, among other things, an attempt to highlight the characteristic stages of the development of Armenian culture, in the first place the written one and especially that of the Middle Ages, in which the influence of the Eastern Roman Empire - Byzantium is very visible. This primarily concerns the maintenance and organization of monasteries, scriptoriums and production of manuscripts. Due to the geographical position of Armenia in the Middle Ages, the appearance of manuscripts was influenced by both Western monarchies and Oriental cultures. In this context, the occupation of Armenia by the Ottoman Empire, which lasted for several hundred years, is another element of similarity between the Armenian and Serbian people.

The work deals with the period from the $5^{\text {th }}$ century AD to the modern age. Particular attention was paid to the monastery scriptoriums and libraries which were, for several centuries and especially in the Middle Ages, the most significant and very often the only guardians of the book and reading cult among the Armenians. Printing and publishing among the Armenians have been developing since the $16^{\text {th }}$ century, and the first book was published in 1512. In the first half of the $19^{\text {th }}$ century, a printing press was opened in the Armenian capital, Yerevan. Until then, books were printed in big trade centers abroad, like Amsterdam, New Julfa, Smirna.

National Library of Armenia was established in 1832. The other types of libraries have been founded since the $19^{\text {th }}$ century. Special, university and public libraries were founded during the first three decades of the $20^{\text {th }}$ century. Modern Armenian librarianship is developing under the influence of new information technologies, without neglecting the written tradition, which has been nourished continuously, for a thousand and six hundred years.

Keywords: Armenia, Christianization, script, book, educational centers, monasteries, scriptoriums, libraries, $5^{\text {th }}-20^{\text {th }}$ centuries, printing, publishing 


\section{(@) $\oplus \Theta$}

Писана традиција Јермена: шеснаест векова писма, књиге и библиотека bу Биљана М. Ђурашиновић is licensed under a Creative Commons Attribution-NonCommercial-NoDerivatives 4.0 International License. 